\title{
Short and long term effects of $1 \%$ atropine drops on tear production in mixed breed dogs
}

\section{Efeitos a curto e longo prazos do colírio de atropina a $1 \%$ sobre a produção lacrimal em cães sem raça definida}

\author{
José Luiz Laus, " Rodrigo Cezar Sanches, ${ }^{*}$ Aline Adriana Bolzan, ${ }^{*}$ Felipe Antônio Mendes Vicenti, ${ }^{*}$ \\ Gener Tadeu Pereira*
}

\begin{abstract}
It was conceived to study the effects of $1 \%$ atropine sulfate drops on tear production in dogs, due to references on its decrease in susceptible animals, treated chronically with the drug, in spite of not being consensus among the authors the possibility of Keratoconjunctivitis Sicca (KCS) induction in these patients. In this context, it was investigated atropine in relation to these intercurrent processes in mixed breed dogs that are little or not susceptible to KCS. For this purpose 20 adult, male, healthy dogs were used. The tear production was evaluated using the Schirmer tear test $n^{\circ} 1$. The study was done in three stages, named pre-atropinic, atropinic and post-atropinic. In the pre and post atropinic stages only one daily measuring of the parameter was taken during 14 and 30 days respectively, without any use of the medication. In the pre-atropinic stage it was possible to establish the value of $20,26 \mathrm{~mm} / \mathrm{min}$ as basal, referring to tear production. The atropinic stage was divided in four periods, having the first measuring before instilling the drug and the others, afterwards, at intervals of one hour, adding up to three measurements, during the 30 days of evaluation. The results allow affirming that topical $1 \%$ atropine sulfate application in dogs brought about a decrease of tear production, with an inclination to normalize after interrupting the treatment.
\end{abstract}

Keywords: atropine, tear production, dogs.

\section{Resumo}

Concebeu-se estudarem os efeitos do colírio de sulfato de atropina a $1 \%$ sobre a produção lacrimal em cães, por existirem referências sobre sua diminuição, em animais susceptíveis, tratados cronicamente com a droga, embora não seja consenso entre os autores a possibilidade de indução de Ceratoconjuntivite Seca (CCS) nestes pacientes. Neste contexto, procurou-se investigar a atropina quanto a estas intercorrências em cães sem raça definida que são pouco ou nada susceptíveis à CCS. Para tanto, foram empregados 20 animais da espécie canina, sem raça definida, machos, adultos e sadios. A lacrimogênese foi avaliada através do teste da lágrima de Schirmer do tipo I. O experimento foi composto por três fases, denominadas préatropínica, atropínica e pós-atropínica. Nas fases pré e pós-atropínica, realizou-se única mensuração diária do parâmetro, durante 14 e 30 dias, respectivamente, não ocorrendo aplicação do medicamento. Na fase pré-atropínica, pôde-se estabelecer como basal o valor de 20,26 mm/minuto, referente à produção lacrimal. A fase atropínica foi dividida em 4 tempos, sendo a primeira mensuração anterior à instilação do fármaco e as demais, posteriores, a intervalos de 1 hora, num total de 3 aferições. Os resultados obtidos permitem afirmar que o emprego tópico do sulfato de atropina a 1\%, em cães, acarretou diminuição na produção da lágrima, com tendência à normalização após a interrupção do tratamento.

Palavras-chave: atropina; produção lacrimal; cães.

\section{Introduction}

The atropine, a parasympatholitic agent used as mydriatic in the ophthalmic examinations and as cycloplegic in the congenital and morganian cataract, in the anterior uveitis and in some types of ceratitis, has been mentioned as capable to decrease tear production (Slatter, 1990 ; Gelatt, 1999).

Tear production can be classified in basal and reflex (Cross, Krupin, 1977 ; Ludders, 1979 ; Gelatt, 1999). The basal or continuous secretion is essential to the precorneal tear film (PTF) formation and maintenance and, consequently, to the integrity of the cornea and the conjunctiva. Light exposition, wind or any other irritating element stimulates reflex tearfulness (Hollingsworth, 1992 ; Gelatt, 1999). The central or retinal reflex stimulus is brought out by luminous rays incidence in the reti$\mathrm{na}$, as the peripheral is unchained by the nervous terminations from the cornea, conjunctiva, uvea and ocular conjoined parts, originated in the ophthalmic branch of the trigeminal nerve (Gelatt, 1999).

The PTF covers the cornea and the conjunctiva (Slatter, 1990). Slatter (1990) and Schoenau, PIPPI (1993) consider PTF inherent to the cornea and partially responsible for its smooth

* Faculdade de Ciências Agrárias e Veterinárias - UNESP, Jaboticabal. Via de acesso Paulo Donato Castellane, Km 5 - zona rural, CEP 14870-000, Jaboticabal, SP, Brasil. E-mail: jllaus@fcav.unesp.br. 
and shiny appearance (Patton, 1955). It consists of three layers: lipidic or external, aqueous or middle and mucoid or inner. It is secreted by the glandular component of the lacrimal system and produced by the lacrimal gland, gland of the nictitating membrane and also the acessory lacrimal glands (Banks, 1992).

The diseases located at the lacrimal gland system can become evident by reduction or lack of tear production and PTF alterations (Gelatt, 1999). Deficiencies in the aqueous portion are more common, however the lipidic or mucoid layers could also be affected (Slatter, 1990).

The Keratoconjunctivitis Sicca (KCS) is a disorder with common occurrence among dogs and is due to a deficiency in the aqueous portion of the tear (Slatter, 1990 ; Gionfriddo, 1995). With multiple ethiology, it could be originated from drug toxicity, surgical or idiopathic causes or elapsed from orbital and supra-orbital traumas, which affect the glands directly or through its innervation. Viral and toxic infections are also incriminated. Even though, in most of the cases the imunomediated is related as the main cause (Gionfriddo, 1995 ; KASWAN et al, 1997). Ulcerative and pigmentary ceratitis are the most commonly mentioned consequences (Kern, 1990). In some cases the abundant presence of mucus can be the only clinical sign (Bounous et al, 1997).

The KCS diagnostic can be obtained through the Schirmer tear test $n^{\circ} 1$, a semi-quantitative method which allows to measure the aqueous portion produced by lacrimal secretion and also indirectly measure the activity of the involved glands (Slatter, 1990 ; Gionfriddo, 1995). The Schirmer tear test no 1 checks the totality of the tear production including the basal tear shedding and the reflex provoked by the contact with the tip of the test stripe (Jones, 1966 ; Hollingsworth, 1992 ; Gelatt, 1999). Basal values for the Schirmer tear test no 1 in dogs are of $20 \mathrm{~mm} / \mathrm{min}$ according to Slatter (1990) and $21 \mathrm{~mm} / \mathrm{min}$ according to Gelatt (1999).

Even though indications point towards insufficient tear production in animals treated with atropine, mentions in this topic are few and often controverted. Considering the great number of ophthalmic diseases in which atropine based drops are used, often in an extended manner, there should be supposed that if there were drastic effects over the tear production, it would motivate innumerous papers; even so, that is not what has been observed. In this manner, the present study aimed to evaluate the correlation among the effects of atropine sulfate instillation through chronic and acute administrations over the crossed breed animals known not to be KCS predisposed.

\section{Material and methods}

There were used 20 mixed breed, healthy and adult male dogs, furnished by the Experimentation Kennel from the Veterinary Hospital "Governador Laudo Natel" of the Faculdade de Ciências Agrárias e Veterinárias - UNESP - Jaboticabal (SP). After the clinic and ophthalmic evaluations, the healthy animals were kept in individual kennels and submitted to an approximate 7 days adaptation period.

Experimentation took place always during the morning time (from 8 to 12 a.m.) trying to minimize any possible day-related variation. Three experimental stages were conceived and denominated pre-atropinic, atropinic and post-atropinic.

Basal and mean values were taken for pre-atropinic stage through daily Schirmer tear test no 1 mensurations of the tear production during 14 days. At this stage a single 8 a.m. mensuration was taken per animal.

For the atropinic stage, $1 \%$ atropine sulfate drops were used for the single instillation at the right eye. The dogs were submitted to Schirmer tear test an hour before the 8 o'clock atropine instillation and every hour for the next 3 hours after its use. The 4 daily measurements were taken during a 30 day period.

The post-atropinic stage consisted of daily mensurations at the same time as those for the atropinic stage, but repeatedly taken during 30 days. The data collected was statistically treated through the test of Tukey and co-variance analysis.

\section{Results}

During the pre-atropinic stage the $20,26 \mathrm{~mm} / \mathrm{min}$ value was observed and assumed as basal or physiological. Its numeric and graphic representations are shown at Table 1 and Figure 1.

Table 1: Schirmer tear test $\mathrm{n}^{\circ} 1$ (STT) mean values during the pre-atropinic, atropinic (composed by 4 periods of time) and the post-atropinic stages with their respective diminishing rates (\%) when compared to the basal value of the pre-atropinic stage

\begin{tabular}{ccc}
\hline Stages & STT $(\mathrm{mm} / \mathrm{min})$ & Basal diminishing rate $(\%)$ \\
\hline Pre-atropinic (basal) & $20.26^{\mathrm{a}}$ & $-\cdots$ \\
Atropinic 1 (0 min) & $20.12^{\mathrm{a}}$ & 0.69 \\
$2(60 \mathrm{~min})$ & $16.52^{\mathrm{b}}$ & 18.46 \\
$3(120 \mathrm{~min})$ & $16.24^{\mathrm{b}}$ & 19.84 \\
$4(180 \mathrm{~min})$ & $17.04^{\mathrm{b}}$ & 15.89 \\
Post-atropinic & $18,38^{\mathrm{c}}$ & 9,28 \\
\hline
\end{tabular}

*averages with \# letters differ from each other at the $5 \%$ statistical significance level

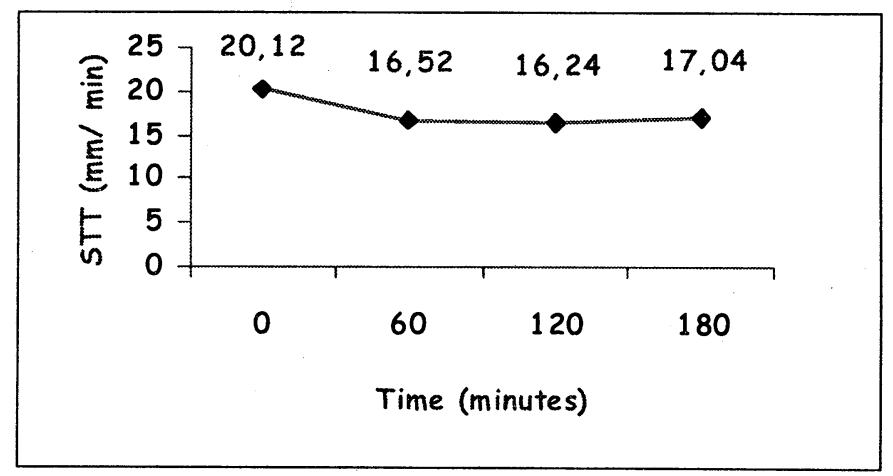

Figure 1: Schirmer tear test $\mathrm{n}^{\circ} 1$ (STT) mean values for aqueous production of the right eye from the 20 dogs treated with the $1 \%$ atropine sulfate drops at the different periods of time of the atropinic stage. 
Mean values for the different periods of time at atropinic stage are graphically represented at Figure 1. During this stage the greatest decrease of the tear production was observed after 120 minutes past the drops instillation at the right eye. At 180 minutes, values for the parameter had increased even though not achieving the one established as basal.

Some statistical significance $(P<0,05 \%)$ was found among the different periods of time of the experimental stages, according to the mensurations mean values for the tear production of the 20 right eyes. It was also observed that the values for the post-atropinic stage were kept diminished and with statistical significance $(P<0,05)$ as shown at Table 1 .

\section{Discussion}

The atropine sulfate is a commonly used drug in ophthalmic therapy. Even though it is referred to as capable of bringing about a decrease of tear production, there are not many papers about the implications of its topic use over the tear production.

Hollingsworth (1992) has recorded lower tear production in dogs 30 minutes past the $1 \%$ atropine sulfate instillation with a maximum decreased value being achieved at 120 minutes and tending towards normality at 300 minutes. These data resemble the ones found in this study, where tear production was reduced after 60 minutes past the atropine instillation with maximum intensity at 120 minutes and elevation past the 180 minutes.

The lower values observed when compared to the basal value are most likely due to a peripheral blockage produced by the atropine and acetylcholine competition for the postganglionary receptors from the parasympathetic system (Gelatt, 1999). Even though the nervous control of the tear production is not completely evident, the inhibition of the efferent stimulus conduction could be responsible for the

\section{References}

BANKS, W.J. Córnea. Histologia Veterinária Aplicada. Louisiana, 1992, p. 593-600.

BOUNOUS, D. et al. Diagnóstico e tratamento da cerato conjuntivite seca. Hora Vet., v. 17, n. 97, p. 76-85, 1997.

CROSS, D.A., KRUPIN, T. Implications of the effects of general anesthesia on basal tear production. Anest. Analg., v. 56, n. 1, p. 35-37, 1977.

GELATT, K.N., PEIFFER, R.L., ERICKSON, J.L. et al. Evaluation of tear formation in the dog, using a modification of the Schirmer tear test. J. Am. Vet. Med. Assoc., v. 166, p. 3368-3370, 1975.

GELATT, K.N. Veterinary ophthalmology. 2. ed. Philadelphia : Lippincott Williams \& Wilkins, 1999.

GIONFRIDDO, J.R. When red eyes are due to preocular tear film disease. Vet. Med. - Symposium on red eye in small animals, p. 256-264, 1995. decrease of tear production (Jones, 1966). The lacrimal gland innervation comes from the lacrimal nerve, which is originated at the ophthalmic nerve, one of the trigeminal branches. The lacrimal nerve is constituted by parasympathetic and sympathetic nervous fibers, with predominance of the colinergic over the adrenergic ones. These colinergic and adrenergic fibers have been recently identified at the lacrimal gland and gland of the nictitante membrane (Gelatt, 1999).

An analysis of the post-atropinic stage compiled data suggests that there is a tendency of basal values achievement 30 days past the treatment interruption, similarly to the data presented by Hollingsworth (1992).

It was verified that the inhibitory effect over the tear secretion lasted through the 30 days of evaluation past the treatment interruption (post-atropinic stage). It is known that the drug long lasting effect is due to the attraction from the iris present melanocytes to the atropine molecule which is captured and slowly eliminated 10 to 14 days past the last instillation (Slatter, 1990).

\section{Conclusions}

This study allowed admitting that:

- The instillation of atropine sulfate leads to a lower tear production in mixed breed.

- The drug should be carefully used in animals with low basal lacrimal values.

- The drug should be carefully used in breeds predisposed to KCS and exposition ceratitis development.

- The tear production should be monitored by Schirmer tear test $n^{\circ} 1$ while using a therapeutic protocol where atropine is included.

HOLLINGSWOTH, S.R. Effect of topically administered atropine on tear production in dogs. Am. J. Vet. Assoc., v. 200 , n. 10, p. 1481-1484, 1992.

JONES, L.T. The lacrimal secretory system and its treatment. Am. J. Ophthalmol., v. 62, p. 47-60, 1966.

KASWAN, R.L., et al. Diagnóstico e tratamento de ceratoconjuntivite seca. Hora Vet., v. 17, n. 97, p. 76-85, 1997.

KERN, T.J. Ulcerative keratitis. Vet. Clin. North Am. Small Anim. Pract., v. 20, n. 3, 1990, p. 643-666.

PATTON, R.T. Keratoplasty. New York : Mc Graw-Hill, 1955. 280 p.

SCHOENAU, L.S.F., PIPI, N.L. Aspectos morfológicos e funcionais da córnea: uma breve revisão. Hora Vet., Porto Alegre, v. 12, n. 72, p. 49-53, 1993.

SLATTER, D. Cornea and sclera. Fundamentals of veterinary ophthalmology. 2. ed: Philadelphia: Saunders, 1990.630 p. 